\title{
XXIX. ON THE LIPOLYTIC ACTION OF THE TISSUES.
}

\author{
BY FRANCIS HUGO THIELE. \\ From the Research Laboratories, University College Hospital \\ Medical School.
}

(Received April 7th, 1913.)

The following experiments were carried out to test the lipolytic activity of the various organs towards the neutral fats.

It is only comparatively recently that such enzymes have been demonstrated in the tissues; their presence was inferred previously from the action of tissue extracts on simple esters, such as monobutyrin, etc. That these are by no means the same, has been shown by Cohnstein [1904] for the castoroil seed. Arthus [1902] showed a similar difference for blood serum.

Nencki and Lüdy [1887] tested the lipolytic power of tissues on amyl salicylate and found that the tissue extracts worked best in an alkaline medium.

Hanriot [1896] used monobutyrin and demonstrated a lipolytic ferment in all tissue extracts except the thyroid. The enzyme ceased to act when a certain degree of acidity had developed and could continue when the acidity was neutralised. He also showed that the tissue extracts could hydrolyse the ethyl esters of formic, acetic, propionic-and butyric acids.

Arthus [1902] drew attention to the errors in Hanriot's observations and was unable to confirm his work. Kastle and Loevenhart [1900] experimented with ethyl butyrate and found that the ferment was closely attached to the cells, and that liver extract was more active than the pancreatic on this ester, but that the pancreas could hydrolyse the esters of the higher fatty acids more readily than those of the lower.

Siebert [1900] studied the action of pancreatic extracts on egg yolk, and further, showed that the blood serum is incapable of splitting lecithin. Subsequently Umber and Brugsch [1906] experimented with tissue extracts, using egg yolk as their emulsion of neutral fat. The various organs were washed free from blood, then finely ground up with kieselguhr and the juice 
pressed out with a hydraulic press. Two series of experiments were performed, one with the organs from an animal killed whilst digesting, the other in starvation. One series of experiments was conducted under aseptic conditions, the other under toluene.

These observers concluded that the tissue extracts can hydrolyse the fat in egg yolk and that during digestion the pancreatic extract is the most powerful, closely followed by that of the spleen, but that the liver and intestinal mucosa are more powerful than the pancreas. Further that activating bodies would appear to be present in some of the organs.

In the following series of experiments it was intended to study the action of the various tissue extracts on:

(1) Egg yolk.

(2) Artificial emulsions of lecithin.

(3) Lecithin not in a state of emulsion.

(4) Chyle obtained from the human subject.

The tissues were ground up finely in a mortar, mixed with an equal bulk of normal saline and pressed through a press so that the tissue extract consisted of a fine suspension of the tissue in normal saline. The tissues were removed under strict aseptic precautions; pigs' and dogs' organs were chiefly used. In the case of the pigs' organs, these were removed in the slaughterhouse in gauze soaked in $2.5 \%$ carbolic, the outside was removed with a sterile knife and the tissue transferred to a sterile mortar and ground up with sterile normal saline. The dogs' tissues were obtained from healthy dogs, which were anaesthetised and bled to death. The animals were subsequently washed out with sterile normal saline. No toluene experiments are recorded, because it was found that even adding toluene up to $2 \%$ did not inhibit the growth of organisms which were capable of splitting up egg yolk very readily. The "fat" containing emulsions were also prepared under strictly aseptic precautions and sterilised.

The mixtures of "fat" and tissue extract were incubated at $37^{\circ}$ for 15-20 hours. At the end of that time they were examined directly and culturally for possible bacterial contamination and any showing this were rejected. The method of estimating the effect of the tissue extracts was to determine the total amount of "fat" present by boiling the mixture of unincubated material with sodium carbonate for some time on the water bath, and then, after acidulating with sulphuric acid, extracting with ether. The ethereal extract, after removal of the mineral acid, was then treated with $\mathrm{N} / 10 \mathrm{KOH}$ to neutralise the fatty acids, and then hydrolysed with alcoholic potash, evaporated, and taken up in water, acidulated with sulphuric acid 
and the liberated fatty acids extracted with ether, which was then freed from sulphuric acid by shaking up with water. The ethereal solution of the fatty acids was titrated against $\mathrm{N} / 10$ alcoholic potash and then reckoned in terms of oleic acid; 1 c.c. $\mathrm{N} / 10 \mathrm{KOH}=0.0282 \mathrm{~g}$. oleic acid. The incubated mixtures were neutralised with sodium carbonate, well heated on the water bath and acidulated with sulphuric acid to liberate the fatty acids which were extracted with ether and purified as before. The amount of fatty acid was thus determined by titration with $\mathrm{N} / 10$ alcoholic potash.

In some of the experiments it became necessary to separate oleic.acid and other high fatty acids from any lower acids, such as lactic acid, which might be formed from the carbohydrates. This was done by having a double series of mixtures; in the one the total fatty acids were determined in the way mentioned above, in the second the mixture, after neutralisation and boiling, was treated with sulphuric acid to liberate the fatty acids and then treated with ammonium sulphate, according to the methods of Magnus Levy, to separate the lower from the higher fatty acids.

A. Effect of tissue extracts of various organs on sterile egg yolk mixture, containing $0.5 \%$ sodium carbonate.

10 c.c. tissue extract was used with 20 c.c. of yolk suspension. Results expressed in c.c. decinormal alkali.

No. of Exp.

Pigs' organs

1

2
3

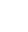
10 c.c. Serum

\begin{tabular}{|c|c|c|}
\hline Pancreas & $\cdots$ & $\cdots$ \\
\hline Liver & $\ldots$ & $\ldots$ \\
\hline Spleen & $\ldots$ & $\ldots$ \\
\hline \multicolumn{3}{|c|}{ Pancreas + 5 c.c. Spleen } \\
\hline "spleen & "was $f$ & $\begin{array}{l}\text { (the } \\
\text { st boiled) }\end{array}$ \\
\hline $\begin{array}{l}\text { Liver }+5 \text { c } \\
\text { Pancreas }+\end{array}$ & & \\
\hline Serum & $\ldots$ & $\ldots$ \\
\hline
\end{tabular}

$\begin{array}{llll}\text { Pancreas } & \ldots & \ldots & \cdots \\ 10 \text { c.c. Bile } & \cdots & \ldots & \cdots\end{array}$

Pancreas +5 c.c. Bile $\ldots .$.

Pancreas + 5 c.c.Bile + 5 c.c. Serum

$\begin{array}{lcc}\text { Pancreas } & \ldots & \ldots \\ \text { Liver } & \ldots & \ldots \\ \text { Kidney } & \ldots & \ldots \\ \text { Muscle } & \ldots & \ldots \\ \text { Spleen } & \ldots & \ldots \\ \text { Pancreas }+5 & \text { c.c. Spleen } \\ \text { Muscle + } 5 \text { c.c. } & \text { Spleen }\end{array}$

\begin{tabular}{|c|c|c|}
\hline $\begin{array}{l}\text { Total fats as } \\
\text { fatty acids }\end{array}$ & $\begin{array}{l}\text { Fatty acids } \\
\text { liberated }\end{array}$ & $\begin{array}{c}\% \text { hydro- } \\
\text { lysed }\end{array}$ \\
\hline $53 \cdot 2$ & $48 \cdot 0$ & $90 \cdot 0$ \\
\hline $55 \cdot 8$ & $20 \cdot 5$ & $36 \cdot 7$ \\
\hline $53 \cdot 8$ & $20 \cdot 2$ & $37 \cdot 5$ \\
\hline $53 \cdot 4$ & $40 \cdot 0$ & $75 \cdot 0$ \\
\hline $53 \cdot 4$ & $40 \cdot 0$ & $75 \cdot 0$ \\
\hline $56 \cdot 0$ & $21 \cdot 6$ & $38 \cdot 6$ \\
\hline $54 \cdot 2$ & $38 \cdot 6$ & $70 \cdot 1$ \\
\hline Not determined & $0 \cdot 0$ & 0.0 \\
\hline $53 \cdot 6$ & $30 \cdot 6$ & $57 \cdot 0$ \\
\hline $51 \cdot 8$ & $19 \cdot 08$ & $36 \cdot 7$ \\
\hline $54 \cdot 0$ & $30 \cdot 0$ & $55 \cdot 5$ \\
\hline $54 \cdot 6$ & $30 \cdot 8$ & $56 \cdot 0$ \\
\hline Not determined & 0.0 & 0.0 \\
\hline $54 \cdot 0$ & $37 \cdot 2$ & $68 \cdot 2$ \\
\hline $55 \cdot 2$ & $21 \cdot 8$ & $39 \cdot 5$ \\
\hline $54 \cdot 6$ & $20 \cdot 4$ & $37 \cdot 87$ \\
\hline $54 \cdot 4$ & $20 \cdot 2$ & $37 \cdot 0$ \\
\hline $54 \cdot 4$ & $21 \cdot 6$ & $40 \cdot 0$ \\
\hline $54 \cdot 8$ & $39 \cdot 1$ & $71 \cdot 0$ \\
\hline $54 \cdot 4$ & $21 \cdot 0$ & $39: 87$ \\
\hline
\end{tabular}


Dogg' Tissues.

5 c.c. of extract +20 c.c. of yolk suspension in each experiment. Results expressed as before.

$\begin{array}{cllllccc} & & & & \text { Total fats } & \text { Fatty acids } & \% \text { hydrolysed } \\ \text { Dog } 1 & \text { Spleen } & \ldots & \ldots & \ldots & 56 \cdot 1 & 20 \cdot 5 & 36 \cdot 5 \\ \text { Hungry } & \text { Liver } & \ldots & \ldots & \ldots & 56 \cdot 8 & 20 \cdot 5 & 36 \cdot 0 \\ \text { animal } & \text { Pancreas } & \ldots & \ldots & \ldots & 55 \cdot 9 & 22 \cdot 8 & 40 \cdot 9 \\ & \text { Kidney } & \ldots & \ldots & \ldots & 56 \cdot 3 & 20 \cdot 2 & 35 \cdot 8 \\ & \text { Liver + Spleen }(5 \text { c.c. of each) } & \ldots & 57 \cdot 1 & 22 \cdot 0 & 38 \cdot 0 \\ & \text { Pancreas + Spleen (5 c.c. of each) } & 56 \cdot 2 & 37 \cdot 0 & 65 \cdot 8 \\ & \text { Pancreas + 5 c.c. of Serum } & \ldots & 58 \cdot 4 & 37 \cdot 5 & 66 \cdot 2\end{array}$

5 c.c. of extract +20 c.c. of yolk suspension in each experiment. Results expressed as before.

\begin{tabular}{|c|c|c|c|c|c|c|c|}
\hline \multirow{7}{*}{$\begin{array}{c}\text { Dog } 2 \\
\text { Digesting } \\
\text { animal }\end{array}$} & \multicolumn{2}{|c|}{ Pancreas $\quad \ldots$} & \multirow{2}{*}{$\begin{array}{l}\ldots \\
\ldots\end{array}$} & \multirow{2}{*}{$\begin{array}{l}\cdots \\
\ldots\end{array}$} & \multirow{2}{*}{$\begin{array}{l}54 \cdot 2 \\
54 \cdot 4\end{array}$} & \multirow{2}{*}{$\begin{array}{l}41 \cdot 0 \\
37 \cdot 0\end{array}$} & \multirow{2}{*}{$\begin{array}{l}75 \cdot 5 \\
68 \cdot 0\end{array}$} \\
\hline & Pancrea & Serum & & & & & \\
\hline & Serum & $\ldots$ & $\ldots$ & $\ldots$ & - & 0.0 & 0.0 \\
\hline & Liver & $\ldots$ & $\ldots$ & $\ldots$ & $55 \cdot 0$ & $20 \cdot 8$ & $37 \cdot 8$ \\
\hline & Spleen & $\ldots$ & $\ldots$ & $\ldots$ & $54 \cdot 3$ & $20 \cdot 2$ & $\mathbf{3 7} \cdot 0$ \\
\hline & Pancrea & Spleen & $\ldots$ & $\ldots$ & $54 \cdot 6$ & $44 \cdot 5$ & $81 \cdot 5$ \\
\hline & Pancrea & oiled & & $\ldots$ & $54 \cdot 6$ & $41 \cdot 5$ & $77 \cdot 0$ \\
\hline
\end{tabular}

5 c.c. of extract +20 c.c. of yolk suspension in each experiment. Results expressed as before.

\begin{tabular}{|c|c|c|}
\hline \multirow{4}{*}{$\begin{array}{c}\text { Dog } 3 \\
\text { Hungry } \\
\text { animal }\end{array}$} & \multirow{2}{*}{\multicolumn{2}{|c|}{$\begin{array}{l}\text { Pancreas } \ldots \\
\text { Pancreas + Liver (5 c.c. of each) }\end{array}$}} \\
\hline & & \\
\hline & Pancrea & plee \\
\hline & Spleen & $\ldots$ \\
\hline & Liver & $\ldots$ \\
\hline
\end{tabular}

Human Tissues.

Removed twelve hours after death. 20 c.c. of egg yolk and 10 c.c. of the tissue suspension. Results expressed as before.

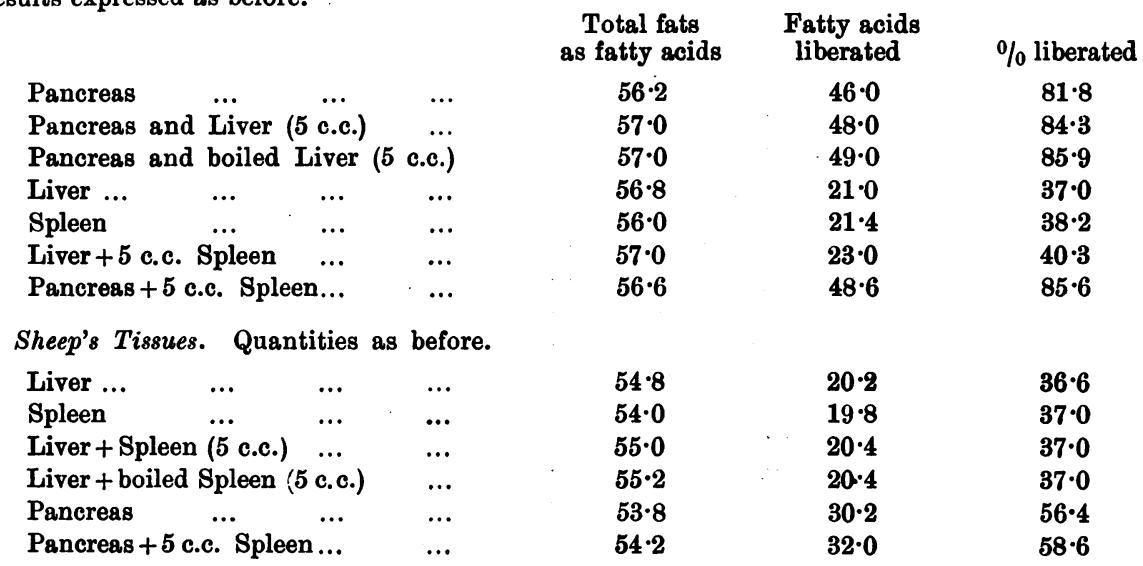

From these experiments it will be seen that the tissues have the power of breaking up the lecithin when it is exhibited to them in the form of egg yolk emulsion.

In all cases the pancreas has a much more powerful action than any other tissue extract, and there is from these experiments no distinct evidence of 
any kinase capable of augmenting the activity of the ferments. The only example of this effect occurs in one of the experiments with the tissues of a $\operatorname{dog}$ in a fasting state, but in the other experiments with the organs of a dog, and with those of pigs and sheep, which are always slaughtered in a fasting condition, there is absolutely no evidence of any activating ferment in any of the tissues. In these respects these experiments do not agree with those of Umber and Brugsch [1906].

The above results, however, like those of Umber and Brugsch, take no notice of the formation of the lower fatty acids, which Magnus Levy [1902] showed were formed during the incubation of tissues from the carbohydrates present. In order, therefore, to eliminate this error, the following experiments were performed in double series; in one the total fatty acids were estimated, in the other the lower fatty acids were estimated after separation by ammonium sulphate, the difference between the two being due to the amount of fatty acid liberated by the hydrolysis of the fat.

In the following series of experiments 10 c.c. of tissue juice were incubated with 20 c.c. of yolk suspension in $0.5 \%$ sodium carbonate at $37^{\circ}$ for 18 hours. The results here are in terms of $\mathrm{N} / 10 \mathrm{NaOH}$ as before.

\begin{tabular}{|c|c|c|c|c|c|c|}
\hline $\begin{array}{l}\text { No. of } \\
\text { Exp. }\end{array}$ & Pigs' & $\begin{array}{l}\text { Total fatty } \\
\text { acids found }\end{array}$ & $\begin{array}{l}\text { Lower fatty } \\
\text { acids }\end{array}$ & $\begin{array}{l}\text { Higher fatty } \\
\text { acids }\end{array}$ & $\begin{array}{l}\text { Total fat } \\
\text { in terms of } \\
\text { fatty acids }\end{array}$ & $\begin{array}{c}\% \text { hydro- } \\
\text { lysed }\end{array}$ \\
\hline \multirow[t]{3}{*}{1} & $\begin{array}{l}\text { Liver } \\
\text { Spleen }\end{array}$ & $\begin{array}{l}23 \cdot 0 \text { c.c. } \\
-21 \cdot 0\end{array}$ & $\begin{array}{l}7 \cdot 6 \text { c.c. } \\
3 \cdot 2\end{array}$ & $\begin{array}{l}15 \cdot 4 \text { c.c. } \\
17 \cdot 8\end{array}$ & $\begin{array}{l}52 \cdot 0 \\
51 \cdot 2\end{array}$ & $\begin{array}{l}29 \cdot 6 \\
34 \cdot 7\end{array}$ \\
\hline & Kidney & $18 \cdot 0$ & $4 \cdot 0$ & $14 \cdot 0$ & $51 \cdot 3$ & $27 \cdot 3$ \\
\hline & Pancreas & $39 \cdot 0$ & $1 \cdot 5$ & $37 \cdot 5$ & $51 \cdot 0$ & $73 \cdot 5$ \\
\hline \multirow[t]{5}{*}{2} & Sheep's & & & & & \\
\hline & Pancreas & $31 \cdot 0$ c.c. & $2 \cdot 0$ c.c. & 29.0 c.c. & $51 \cdot 0$ & $56 \cdot 8$ \\
\hline & Liver & $19 \cdot 0$ & $6 \cdot 1$ & $12 \cdot 9$ & $51 \cdot 8$ & $27 \cdot 9$ \\
\hline & Spleen & $12 \cdot 8$ & $1 \cdot 8$ & $11 \cdot 0$ & $51 \cdot 2$ & $21 \cdot 5$ \\
\hline & Kidney & $13 \cdot 2$ & $4 \cdot 0$ & $9 \cdot 2$ & $51 \cdot 4$ & $17 \cdot 9$ \\
\hline \multirow[t]{5}{*}{3} & Dogs' & & & & & \\
\hline & Pancreas & 38.0 c.c. & $1 \cdot 4$ c.c. & $36 \cdot 6$ c.c. & $49 \cdot 2$ & $74 \cdot 4$ \\
\hline & Liver & $18 \cdot 0$ & $4 \cdot 1$ & $13 \cdot 9$ & $49 \cdot 8$ & $27 \cdot 8$ \\
\hline & Spleen & $17 \cdot 0$ & $5 \cdot 7$ & $11 \cdot 3$ & $49 \cdot 0$ & $23 \cdot 0$ \\
\hline & Muscle & $12 \cdot 0$ & $5 \cdot 2$ & $6 \cdot 8$ & $49 \cdot 3$ & $13 \cdot 7$ \\
\hline
\end{tabular}

These experiments do not very greatly alter the results of the previous experiments, and confirm the lipolytic power of the various tissue extracts towards egg yolk emulsion.

B. Experiments with liver extracts on lecithin, not in a state of emulsion.

Weighed quantities of lecithin were placed in sterile flasks and sterilised. Then sterile tissue extract was added and allowed to act for varying intervals in the cold or warm. 


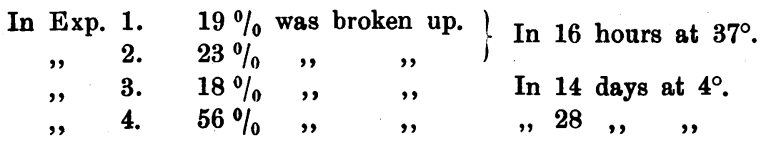

The result in each case should be somewhat higher, because no account was taken of the amount of lecithin in the liver extract added. It is interesting to note that jecorin could also be found in all these experiments after incubation.

\section{Action of tissue extracts on chyle.}

The chyle was obtained from a healthy young man suffering from lymphatic obstruction, producing lymphangiectasis in one lower limb. The chyle could be obtained under aseptic conditions in large quantities after a period of blocking the fistulae in the lower limb. It contained from 1.3 to $1.6 \mathrm{~g}$. of fat per cent., and from 0.064 to $0.08 \mathrm{~g}$. of lecithin.

The lipolytic ferment in the chyle was destroyed by heating to $60^{\circ}$ for an hour, thus also sterilising the fluid.

Sodium carbonate was added to make a $0.5 \%$ solution.

In these experiments a double series was made in order to determine the relative amounts of higher and lower fatty acids.

20 c.c. of extract of the finely pounded tissue were added to 50 c.c. of chyle and incubated for 18 hours at $37^{\circ}$. Results expressed in c.c. of N/10 NaOH.

\begin{tabular}{|c|c|c|c|c|c|c|}
\hline $\begin{array}{l}\text { No. of } \\
\text { Exp. }\end{array}$ & Pigs' & Total fats & $\begin{array}{l}\text { Fatty acids } \\
\text { found }\end{array}$ & $\begin{array}{l}\text { Lower futty } \\
\text { acids }\end{array}$ & $\begin{array}{l}\text { Higher fatty } \\
\text { acids }\end{array}$ & $\begin{array}{c}\% \text { hydro. } \\
\text { lysed }\end{array}$ \\
\hline \multirow[t]{4}{*}{1} & Pancreas & $24 \cdot 0$ & $18 \cdot 8$ & $1 \cdot 6$ & $17 \cdot 2$ & $71 \cdot 5$ \\
\hline & Liver & $27 \cdot 2$ & $13 \cdot 0$ & $6 \cdot 4$ & $6 \cdot 6$ & $24 \cdot 2$ \\
\hline & Spleen & $23 \cdot 1$ & $5 \cdot 6$ & $2 \cdot 6$ & $3 \cdot 0$ & $13 \cdot 0$ \\
\hline & Kidney & $24 \cdot 8$ & $9 \cdot 4$ & $4 \cdot 2$ & $5 \cdot 2$ & $21 \cdot 0$ \\
\hline \multirow[t]{5}{*}{2} & Pigs' & & & & & \\
\hline & Pancreas & $22 \cdot 9$ & $14 \cdot 2$ & 0.8 & $13 \cdot 4$ & 58.5 \\
\hline & Liver & $25 \cdot 8$ & $9 \cdot 2$ & $3 \cdot 8$ & $5 \cdot 4$ & $20 \cdot 9$ \\
\hline & Spleen & $23 \cdot 2$ & $7 \cdot 4$ & $4 \cdot 8$ & $2 \cdot 6$ & $11 \cdot 2$ \\
\hline & Kidney & $24 \cdot 4$ & $6 \cdot 8$ & $3 \cdot 0$ & $3 \cdot 8$ & $15 \cdot 6$ \\
\hline \multirow[t]{5}{*}{3} & Sheep's & & & & & \\
\hline & Pancreas & $22 \cdot 0$ & $13 \cdot 2$ & $1 \cdot 0$ & $12 \cdot 2$ & $55 \cdot 4$ \\
\hline & Liver & $27 \cdot 1$ & $9 \cdot 2$ & $4 \cdot 0$ & $5 \cdot 2$ & $18 \cdot 0$ \\
\hline & Spleen & $22 \cdot 4$ & $5 \cdot 6$ & $3 \cdot 2$ & $2 \cdot 4$ & $10 \cdot 7$ \\
\hline & Kidney & $25 \cdot 0$ & $6 \cdot 0$ & $2 \cdot 0$ & $4 \cdot 0$ & $16 \cdot 0$ \\
\hline \multirow[t]{5}{*}{4} & Dogs' & & & & & \\
\hline & Pancreas(10c.c. & c.) $21 \cdot 6$ & $15 \cdot 0$ & $1 \cdot 0$ & $14 \cdot 0$ & $65 \cdot 0$ \\
\hline & Liver & $30 \cdot 3$ & $13 \cdot 4$ & $4 \cdot 2$ & $9 \cdot 2$ & $30 \cdot 3$ \\
\hline & Spleen & $24 \cdot 7$ & $6 \cdot 5$ & $2 \cdot 8$ & $3 \cdot 7$ & $15 \cdot 0$ \\
\hline & Kidney & $26 \cdot 6$ & $8 \cdot 2$ & $3 \cdot 1$ & $5 \cdot 1$ & $20 \cdot 0$ \\
\hline
\end{tabular}

These results show that a certain amount of the fatty acids found in the 
incubated mixture is due to the formation of lower fatty acids. Further, that the tissues have the power of liberating higher fatty acids when incubated with chyle, but as chyle and the tissues contain not only neutral fat, but lecithin as well, the question then arises as to the relative proportion hydrolysed by the tissue ferments. Finally the figures are quite small when compared with those obtained by using egg yolk.

To determine this question a series of experiments was carried out in which the lecithin, the total amount of fats and the higher fatty acids formed were determined before and after incubation.

For this purpose three sets of each mixture were made. The lecithin was determined by extracting the material with alcohol and ether, evaporating, taking up in ether, precipitating by acetone and determining the phosphorus in the precipitate by Neumann's method.

1 c.c. $\mathrm{N} / 2 \mathrm{NaOH}=0.014331$ g. of lecithin.

Lecithin contains $66 \%$ fatty acids.

Quantities as before. Results reckoned as fatty acids in terms of N/10 alkali.

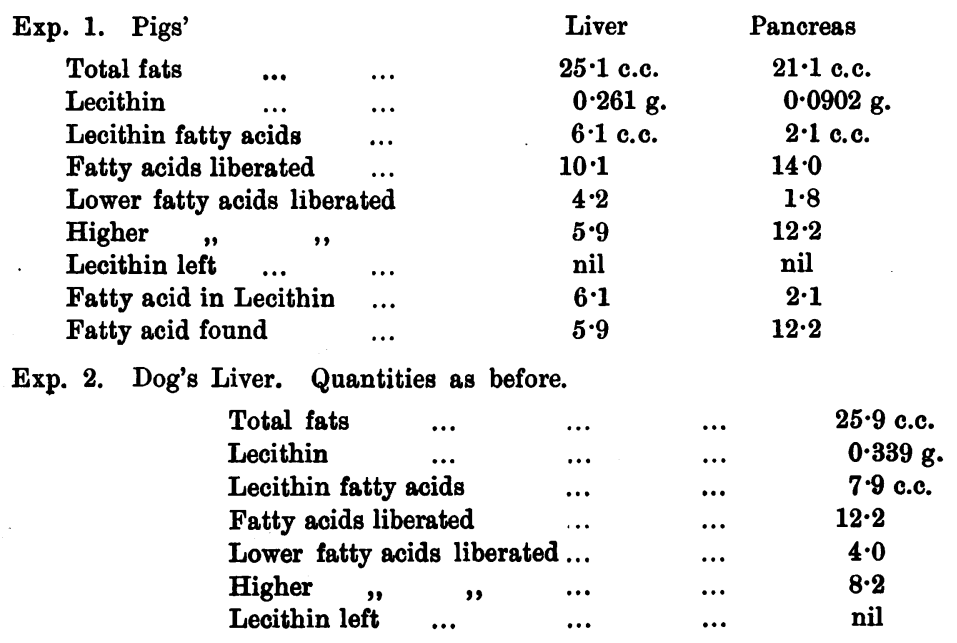

Exp. 3. Quantities as before.

Fatty acids in the lecithin $=7 \cdot 9$ c.c. $\mathrm{N} / 10 \mathrm{NaOH}$.

, , found liberated $=8 \cdot 2$, ,

\begin{tabular}{|c|c|c|c|}
\hline Sheep's & Liver & Spleen & Kidney \\
\hline Total fats as fatty acids .. & 30.4 c.c. & $28 \cdot 9$ c.c. & $30 \cdot 2$ c.c. \\
\hline Lecithin $\quad \ldots$ & $0.244 \mathrm{~g}$ & $0 \cdot 177 \mathrm{~g}$. & $0.235 \mathrm{~g}$. \\
\hline Fatty acids in Lecithins .. & $5 \cdot 7$ c.c. & $4 \cdot 2$ c.c. & $5 \cdot 5$ c.c. \\
\hline Fatty acids liberated .. & $11 \cdot 3$ & $8 \cdot 4$ & $7 \cdot 8$ \\
\hline Higher fatty acids liberate & $5 \cdot 5$ & $3 \cdot 9$ & $5 \cdot 3$ \\
\hline Lower & $5 \cdot 8$ & $4 \cdot 5$ & $2 \cdot 5$ \\
\hline Lecithin left & nil & nil & nil \\
\hline
\end{tabular}




\begin{tabular}{|c|c|c|c|c|c|c|}
\hline \multicolumn{3}{|c|}{ Exp. 4. Pigs' } & Liver & Kidney & Spleen & $\begin{array}{l}\text { Spleen + Liver } \\
\text { (10 c.c. of each) }\end{array}$ \\
\hline \multirow{4}{*}{\multicolumn{3}{|c|}{$\begin{array}{lll}\text { Total fats } & \ldots & \ldots \\
\text { Lecithin } & \ldots & \ldots \\
\text { Fatty acid in lecithin } & \ldots \\
\text { Fatty acids liberated } & \ldots \\
\text { Lower fatty acids liberated }\end{array}$}} & 26.8 c.c. & $25 \cdot 4$ c.c. & $24 \cdot 2$ c.c. & $21 \cdot 1$ c.c. \\
\hline & & & $0.2178 \mathrm{~g}$. & $0 \cdot 1576 \mathrm{~g}$. & $0 \cdot 1089 \mathrm{~g}$. & $0.3152 \mathrm{~g}$. \\
\hline & & & $\begin{array}{l}5 \cdot 1 \text { c.c. } \\
8 \cdot 3\end{array}$ & $\begin{array}{l}3 \cdot 7 \text { c.c. } \\
5 \cdot 2\end{array}$ & $\begin{array}{l}2 \cdot 6 \text { c.c. } \\
6 \cdot 5\end{array}$ & $\begin{array}{l}7 \cdot 4 \text { c.c. } \\
13 \cdot 7\end{array}$ \\
\hline & & & $2 \cdot 8$ & $2 \cdot 1$ & $4 \cdot 0$ & $6 \cdot 1$ \\
\hline \multirow{2}{*}{$\begin{array}{l}\text { Higher ", } \\
\text { Lecithin }\end{array}$} & ", & & $5 \cdot 5$ & $3 \cdot 1$ & $2 \cdot \check{0}$ & $7 \cdot 6$ \\
\hline & $\ldots$ & $\ldots$ & nil & trace & nil & nil \\
\hline
\end{tabular}

In all these experiments it will be noticed, with the exception of that with pancreatic extract, that the amount of fatty acids liberated corresponds to the amount of fatty acids present in the lecithin; and that in all cases the lecithin is practically completely hydrolysed.

Evidence of the inability of the lipase of the liver to attack neutral fat is obtained from experiments on aseptic autolysis at $4^{\circ}$. Fat expressed as c.c. $\mathrm{N} / 10 \mathrm{NaOH} \%$.

$\begin{array}{ccc}\begin{array}{c}\text { Duration of } \\ \text { autolysis (days) }\end{array} & \begin{array}{c}\text { Dogs' } \\ \text { Tissues }\end{array} & \begin{array}{c}\text { Sheep's } \\ \text { Tissues }\end{array} \\ 0 & 16 \cdot 2 & 21 \cdot 0 \\ 7 & 16 \cdot 6 & 20 \cdot 4 \\ 21 & 15 \cdot 8 & 21 \cdot 6 \\ 42 & 16 \cdot 2 & 22 \cdot 4 \\ 91 & 16 \cdot 8 & - \\ 168 & - & 22 \cdot 8 \\ 224 & - & 22 \cdot 4\end{array}$

This shows that ordinary fat is not hydrolysed, but that lecithin is hydrolysed at $4^{\circ}$. These results indicate that the liver, spleen and kidney contain a lipolytic ferment which attacks lecithin quite readily, but has no apparent action on the simple glycerides of the higher fatty acids even when presented in the form of the finest emulsion as in chyle, or as they exist in the tissue itself as is seen in the autolytic experiments.

It is possible that the reason of this lies in the fact that lecithin can form in water a colloid suspension, and so can be more readily attacked, but the previous results show that lecithin can be readily split up even when presented to the tissue extracts in a very coarse form. The other and more probable explanation would appear to be that when the glycerides of the higher fatty acids are taken to the liver or other tissues they are converted into lecithins and stored up free or in combination with the protein as the invisible unstainable fat in the normal organ and in this form are easily hydrolysed by the lipolytic ferment as required. This view seems the more probable from the results of Leathes and Kennaway [1909], who showed that the liver desaturates fats brought from the food or fat depots; this agrees with the high iodine values of the lecithins, showing that the lecithins are 
formed from these desaturated fatty acids. Further, it is important to note in the quantitative estimations of the "fats" in the liver, etc., that by far the greatest amount is accounted for by the lecithins, nearly $90 \%$.

\section{Experiments to ascertain the effect of reaction on the} lipolytic power of the organs.

In each of these a double series of experiments was performed to ascertain the amount of higher fatty acids.

Pig's Liver. 10 c.c. of extract with 20 c.c. of egg yolk suspension.

1. Effect of Alkali.

\begin{tabular}{|c|c|c|c|c|c|c|}
\hline With g. $\mathrm{Na}_{2} \mathrm{CO}_{3}$ & $(\%)$ & $\begin{array}{c}\text { Total } \\
\text { fatty acids }\end{array}$ & Lower & Higher & $\begin{array}{c}\text { Total } \\
\text { fat }\end{array}$ & $\%$ hydrolysed \\
\hline 0.05 & $(0 \cdot 16)$ & $14 \cdot 4$ & $6 \cdot 0$ & $8 \cdot 4$ & $40 \cdot 8$ & $20 \cdot 7$ \\
\hline $0 \cdot 1$ & $(0.32)$ & $21 \cdot 6$ & $7 \cdot 6$ & $14 \cdot 0$ & $40 \cdot 8$ & $34 \cdot 3$ \\
\hline $0 \cdot 15$ & $(0.5)$ & $23 \cdot 2$ & $7 \cdot 4$ & $15 \cdot 8$ & $40 \cdot 8$ & $38 \cdot 7$ \\
\hline 0.2 & $(0.66)$ & $18 \cdot 2$ & $6 \cdot 1$ & $12 \cdot 1$ & $40 \cdot 8$ & $29 \cdot 6$ \\
\hline 0.3 & $(1 \cdot 0)$ & $10 \cdot 1$ & $4 \cdot 0$ & $6 \cdot 1$ &, & $14 \cdot 9$ \\
\hline 0.4 & $(\mathbf{1} \cdot \mathbf{3 3})$ & $6 \cdot 0$ & $2 \cdot 1$ & 3.9 & ,, & $9 \cdot 0$ \\
\hline
\end{tabular}

Same quantities as above, but 30 c.c. water added.

\begin{tabular}{|c|c|c|c|c|c|c|}
\hline 0.05 & $(0.08)$ & 12.5 & $4 \cdot 6$ & $7 \cdot 9$ & $40 \cdot 2$ & $19 \cdot 6$ \\
\hline 0.1 & $(0 \cdot 16)$ & $20 \cdot 0$ & $6 \cdot 0$ & $14 \cdot 0$ & , & $34: 8$ \\
\hline $0 \cdot 15$ & $(0.24)$ & $21 \cdot 4$ & $6 \cdot 6$ & $14 \cdot 8$ & ," & $36 \cdot 8$ \\
\hline 0.2 & $(0.33)$ & $16 \cdot 2$ & $4 \cdot 6$ & $11 \cdot 8$ & ," & $29 \cdot 3$ \\
\hline 0.3 & $(0.5)$ & $9 \cdot 3$ & $2 \cdot 4$ & $5 \cdot 9$ & ," & $14 \cdot 6$ \\
\hline 0.4 & $(0.66)$ & $5 \cdot 0$ & $2 \cdot 0$ & $5 \cdot 0$ & , & $7 \cdot 4$ \\
\hline
\end{tabular}

Thus it will be seen that the activity does not depend on the percentage of alkali present, but on the total amount.

2. Effect of lactic acid. The quantities used were as before. Incubation 16 hours. The amount of lactic acid is in c.c. of the decinormal solution.

Dog's Liver. 10 c.c. of extract with 20 c.c. of egg yolk solution and all made up to 40 c.c.

$\begin{array}{cccccc}\text { C.c. } \text { N/10 acid } & \begin{array}{c}\text { Total fats } \\ \text { c.c. N/10 alk }\end{array} & \begin{array}{c}\text { Total fatty } \\ \text { acids found }\end{array} & \text { Lower } & \text { Higher } & \text { \% hydrolysed } \\ 2 & 48 \cdot 2 & 20 \cdot 2 & 6 \cdot 8 & 13 \cdot 4 & 27 \cdot 8 \\ 4 & ", & 23 \cdot 8 & 7 \cdot 9 & 15 \cdot 9 & 32 \cdot 9 \\ 6 & ", & 24 \cdot 9 & 9 \cdot 3 & 15 \cdot 6 & 32 \cdot 6 \\ 8 & ", & 23 \cdot 1 & 12 \cdot 4 & 10 \cdot 7 & 22 \cdot 2 \\ 10 & \text { " } & 20 \cdot 8 & 13 \cdot 0 & 7 \cdot 8 & 16 \cdot 2\end{array}$

Pig's Liver. Quantities as above.

$\begin{array}{rcrrrr}2 & 48 \cdot 2 & 18 \cdot 6 & 8 \cdot 1 & 10 \cdot 5 & 21 \cdot 8 \\ 4 & " & 23 \cdot 8 & 9 \cdot 7 & 14 \cdot 1 & 29 \cdot 2 \\ 6 & ", & 24 \cdot 2 & 10 \cdot 4 & 9 \cdot 8 & 20 \cdot 3 \\ 8 & ", & 21 \cdot 2 & 11 \cdot 8 & 9 \cdot 4 & 19 \cdot 5 \\ 10 & , & 19 \cdot 8 & 14 \cdot 1 & 5 \cdot 7 & 11 \cdot 8\end{array}$




\section{SUMmaRY.}

From these experiments we can conclude that:

(1) The tissues possess a true lipolytic ferment.

(2) The lipolytic ferment, with the exception of the pancreatic lipolytic ferment, can only hydrolyse phosphatides and jecorins, but not ordinary fats.

(3) The ferment is capable of acting in an alkaline or acid medium.

(4) There is no evidence of a kinase in the spleen.

Part of the expenses of this research were defrayed by a grant from the Government Grant Committee, Royal Society, London.

\section{REFERENCES.}

Arthus (1902), J. Physiologie, 4, 56.

Cohnstein (1904), Ergebnisse der Physiologie, 3, 194.

Hanriot (1896), Compt. Rend. 123, 753, 833.

Kastle and Loevenhart (1900), Anver. Chem. J. 24, 491.

Leathes and Kennaway (1909), Lancet, 95.

Magnus Levy (1902), Beiträge, 2, 201.

Nencki and Lüdy (1887), Therap. Monatsheft, 417.

Siebert (1900), Zeitsch. physiol. Chemie, 49, 50.

Slade (1903), Beiträge, 3, 291.

Umber and Brugsch (1906), Arch. Exp. Path. 55, 164. 